\title{
Climate Variability, Environment Change and Food Security Nexus in Nigeria
}

\author{
Emeka E. Obioha \\ Department of Social Anthropology and Sociology, National University of Lesotho, \\ Roma, Lesotho, Southern Africa \\ E-mail: eeobioha@yahoo.com
}

KEYWORDS Climate Change. Environment. Food Production. Food Security. Nigeria

\begin{abstract}
This paper investigates the chain of interactions between climatic change, drought condition and food production in Nigeria. The paper relied mainly on secondary data that were generated through the analysis of relevant data from government and non-governmental agencies. From these sources, both quantitative and qualitative information were collected depending on the immediate importance. Among other things, this paper addresses the estimate of drought condition in the savannah region of Nigeria, the nature of food production activities in the area and the extent to which continuous climatic change has affected the state of food production. The paper also examines the indigenous and formal institutional frameworks in addressing the situation for assured food security in Nigeria.The paper concludes from the findings that desertification has impacted negatively on the food production activities in the region, which has necessitated the intervention of the government through the assistance from the international development agencies to combat the problem.
\end{abstract}

\section{INTRODUCTION}

The suitability of the environment to provide all life support systems and the materials for fulfilling all developmental aspirations of man and animal is dependent on the stability of the climate which is undergoing constant changes. The effect of these changes is posing threat to food security in Nigeria. The world had gone through series of climatic epochs, which include the ice age, and consequently, the ice recessions among others. In the recent times, Inter-governmental Panel on Climate Change (IPCC), World Meteorological Organization (NMO) and United Nations Environment Programme (UNEP) established that the earth has become warmer over the last century. According to these agencies, the average surface temperature of the earth has increased during the twentieth century by about $0.6 \pm 0.2^{\circ} \mathrm{C}$. It is warmer presently in many parts of the World than at any time during the past 1000 years, with possibilities of warmest years than the e previous centuries, occurring within the next few decades. This change in temperature usually lead to lower ozone levels near the earth's surface, and significant increase of Smog problems in the cities where the release of carbon dioxide is greater (Obioha 2008: 1).

Compared with other regions of the World, Africa, especially, the sub-Saharan region is the second adversely affected by drought condition and other hydro-meteorological natural disasters after Asia, (Table 1). As in most other countries of the World, the Nigerian environment presents a grim litany of woes (FGN, 1997). Every part of the federation suffers from one form of environmental problem or the other in varying degrees. The northern part (Savannah) of the country is being "blown away" by wind erosion while most southern part (forest) is being washed away into the ocean by erosions.

Recognizing that Nigeria is confronted by major environmental problems, one of the most important is drought. Drought is an insidious hazard of nature that originates from a deficiency of precipitation over a long extended period of time, usually a reason or more, which results in water shortage in the environment (Okorie 2003). It occurs whenever the supply of moisture from precipitation or moisture stored in the soil is

Table 1: Effects of drought on population

\begin{tabular}{lcc}
\hline Region & $\begin{array}{c}\text { Total number } \\
\text { affected, } \\
1975-2001 \\
\text { (millions) }\end{array}$ & $\begin{array}{c}\text { No of people } \\
\text { affected per } \\
\text { occurrence } \\
\text { (millions) }\end{array}$ \\
\hline Africa & 222.1 & 0.87 \\
Asia & 1095.83 & 9.36 \\
Latin America & 47.89 & 0.72 \\
Oceania & 8.65 & 0.39 \\
Europe & 6 & 0.27 \\
North America & 0.03 & 0.0025 \\
\hline
\end{tabular}

Source: Underlying data from Reuveny (2005) 
insufficient to fulfill the optimum water needs of plants, which can be categorized into four types ${ }^{1}$. Drought should be considered relative to some long-term average condition of balance between precipitation and evapo-transpiration (evaporation + transpiration). It is also somewhat related to the timing and effectiveness of rains from the perspective of principal season of occurrence and delays in the start of rainy season and occurrence of rains in relation to principal crop growth stages. More importantly, rainfall intensity and number of rainfall events are important benchmarks for ascertaining drought in an environment. Drought ${ }^{2}$ as defined above may be perceived from discipline-wise perspective, in which meteorology, agriculture or hydrology all shed light on its manifestation and impact.

Wind erosion could be quite severe in most Sahel states of Sokoto, Zamfara, Kebbi, Katsina, Kano, Jigawa, Borno, Yobe, Kano, Adamawa and Bauchi as a result of drought conditions in the area. Climate variability resulting to drought incidence is not new in the savannah region of Nigeria considering the fact that some of the region, especially the Sahel is susceptible to climatic anomalies. The most part of northern Nigeria which was mainly Sudan Savannah is increasingly becoming an arid environment at a very fast receding rate per year occasioned by fast reduction of the amount of surface water, flora and fauna resources on the land. Land cover changes are indeed important index of climate change in Nigeria and other countries. Nigeria is presently losing about 351,000 square kilometers of its landmass to the desert, which is advancing southward at the rate of 0.6 kilometers annually. The consistent reduction in rainfall leads to a reduction in the natural regeneration rate of land resources, which presents a chain of causal reaction that, makes people to exploit more previously undisturbed lands leading to depletion of the forest cover and increase on the sand dunes/Aeolian deposits. The strong and worrisome increase of $425 \%$ in the extent of sand dunes/Aeolian deposits between 1976 and 1995 is a strong pointer to land resource loss due to climate change (Fasona and Omojola 2005) and possibilities of desert encroachment around the northern axis of Nigeria. . As a result of increasing dryness and accumulation of sand, farmlands become inundated by drifting sands, which bury crops, roads, huts and other public buildings, and in extreme case entire villages buried under sand dunes.
Previous studies in the Savannah, particularly in the sahel region of Nigeria (Fiki and Lee 2004; Nyong and Fiki 2005; Obioha 2005) have highlighted some aspects of population drift, violent conflict, conflict generation, conflict management, and self - organizing capabilities in drought - prone in the area, but this present study seeks to integrate food production and security as the fulcrum of analysis. In other words, an attempt is made to understand the role of drought in the question of food availability. In relation to other issues, perhaps more spectacular and of grave consequence of persistent droughts is food insecurity which had occurred in northern part of Nigeria in the recent past. For instance during the 1972-1973 drought in northern Nigeria, about 300,000 animals died and farm yields dropped by up to $60 \%$ in Nigeria. This implies that drought may portend adverse effect on food production and security ${ }^{3}$. However, the extent to which food production and security problem arise from drought phenomenon in Nigeria is not very certain.

Nigeria may not be an exception in the above problem if the rate of desertification continues without adequate checks, especially as there are obvious indications of food insecurity in the country as a result of other economic factors. The issue of food insecurity is of high importance to Nigeria because average calorie and protein intake is grossly inadequate. Estimates showed that at least $41 \%$ of the population is foodinsecure; with 16 percent being severely undernourished (Olayemi 1996). The daily per capital calorie supply as a proportion of requirement was 90 percent between 1988-90; 85 percent between 1992-96 (FOS 1999). Following the above, the need to be fore armed about the devastating effect of drought on food production activities and security motivates this discourse as the draught problem persists in the country.

The main objective of this paper is to demonstrate the chain of interactions between climate changes, drought condition and food production in Nigeria. Specific objectives include to describe the climate condition and vegetation in Nigeria (particularly the savannah), examine the drought condition in the savannah over the years through rainfall, examine the nature of food production activities in the area and scertain the impact of climate change (drought) on food production and security

The location or region under analysis lies 
about $7^{\circ} \mathrm{N}$ and $11.5^{\circ} \mathrm{N}$ and comprises of Guinea, Sudan and Sahel Savannah fromLokoja, Markudi, Ilorin in the southern part of the region to Gussa, Sokoto, Katsina, and Maiduguri in the north most fringes. Rainfall in the Guinea Sudan and Sahel Zone (GSSZ) ${ }^{4}$ is however largely seasonal and vary from year to year. The region is rich in agricultural production but the large inter annual variability of rainfall subjects it to frequent dry spells, which sometimes result in severe and widespread drought that imposes serious socioeconomic constraints. Agriculture through irrigation is widely practiced in order to improve on soil moisture content. Major crops include grains such as rice, wheat, soybeans, beans, maize, millet, sorghum found mainly from the Guinea savannah. Cotton, groundnut and livestock production are mainly concentrated in the Sudan and Sahel savannah region.

\section{SCOPE AND METHODOLOGY}

This article covers period 1991-2004; however, there may be no restriction on discussion to this specific period where there are data that cover longer or shorter time frame. The paper relied mainly on secondary data that were generated through the growth analysis of relevant data from government and non-governmental agencies, such as, National Bureau of Statistics (NBS) Statistical fact sheets on Economic and Social Development, Annual Abstract of Statistic, Central Bank of Nigeria Annual Report and Statement of Account, Journals, Newspapers and other periodicals. Data related to climate, population, food production, food security and conflict were sought. For food production, to be more specific, grains that are predominantly grown in the Savannah region were the selected crops, which their production was used as the indicator for food production.

\section{THEORETICAL FRAMEWORK}

In this section the theoretical framework of analyzing inter-linkage between environmental changes, possible conflict situation and food security is presented. Without the full understanding of the intervening factors, it may be difficult to grasp the true nature of the relationship between these variables in the Savannah climate region of Nigeria. This discourse utilizes some theoretical orientations from earlier scholars in examining environment resource nexus. Prominent among these works are those of Hommer-Dixon of the Toronto School of thought.

The illustration suggested by Hormer-Dioxon implies that the total effect of human activity on the environment in a particular ecological zone is mainly a function of two variables: first, the product of total population in the region and physical activity per capita ${ }^{5}$ and second, the vulnerability of the ecosystem in that region to those particular activities. The theory also emphasized that environmental effects may cause "social effects" that in turn could lead to conflict. For instance desert encroachment on landmass may produce large-scale migration, which could create ethnic conflicts as migratory groups clash with indigenous (settled) populations. Within this paradigm, we must be aware of the interviewing role of population growth, demographic structure, and patterns of population distribution. (Simon 1981; McNicoll 1984; Ehrlich and Ehrlich 1990). Similarly, researchers must understand the effect of the ideational-factors ${ }^{6}$ in conflict generation. The threshold beyond or within which given societies could respond effectively to the inbuilt stress induced by climate/environmental change differs. Particularly, if we wish to understand a society's propensity towards conflict, given certain social effects due to the environmental stress, we need to understand the relationship, between the ideational factors and conflict. However, environmental stress and consequent conflict relation does not occur if environmental and resource scarcity threshold is not attained. The thresh-hold of environmental scarcity could be attained as a result of interaction of sources of scarcity in a particular environment as proposed by Homer-Dixon (1994). According to him, the three sources of environmental scarcity often interact; in two distinct patterns "resource capture" and "ecological marginalization" (see Fig. 1).

Resource capture depicts a situation where a fall in the quantity and quality of renewable resources can combine with population growth to encourage powerful or advantaged groups within a society to shift resource distribution in their favour. This usually produces acute environmental scarcity for poorer and weaker groups whose claims to resources are opposed by more powerful groups. On the other hand, unequal resource access can combine with 
population growth to cause migration to regions that are ecologically fragile, such as steep upland slopes, areas at risk of desertification, and tropical rain forests.

High population densities in these areas, combined with a lack of knowledge and capital to protect local resources, causes severe environmental damage and chronic poverty. The second process is usually called "ecological marginalisation” (Homer-Dixon, 1994).

\section{CLIMATE VARIABILITY AND VEGETATION OF NIGERIAN SAVANNAH}

Nigeria's climate is characterized by extreme humid weather condition in the forest southern region and extreme dry conditions in the savannah region of the north. For the purpose of clarity and detail as shown in Table 2, Nigeria is divided into ultra humid, very humid, humid, subhumid, plateau, mountain, dry humid and semi arid ecological zones. The highest annual rainfall length (mm p.a) ranges from $2000+\mathrm{mm}$ in the ultra humid region down to $200-400 \mathrm{~mm}$ in the semi arid zone of the north. Similarly, the monthly maximum mean range for temperature is $40^{\circ} \mathrm{C}$ in the semi arid down to $31^{\circ} \mathrm{C}$ in the plateau zone. The minimum mean range of temperature is lowest in the mountain zone at $5^{\circ} \mathrm{C}$ compared to $23^{\circ} \mathrm{C}$ in the ultra humid climate zone.

The delineation of the Guinea Savanna Zone from the other two climate zones in the Savannah region is based on the mean annual rainfall as well as the severity of the dry season. The southern limit of Guinea Savanna zone is based

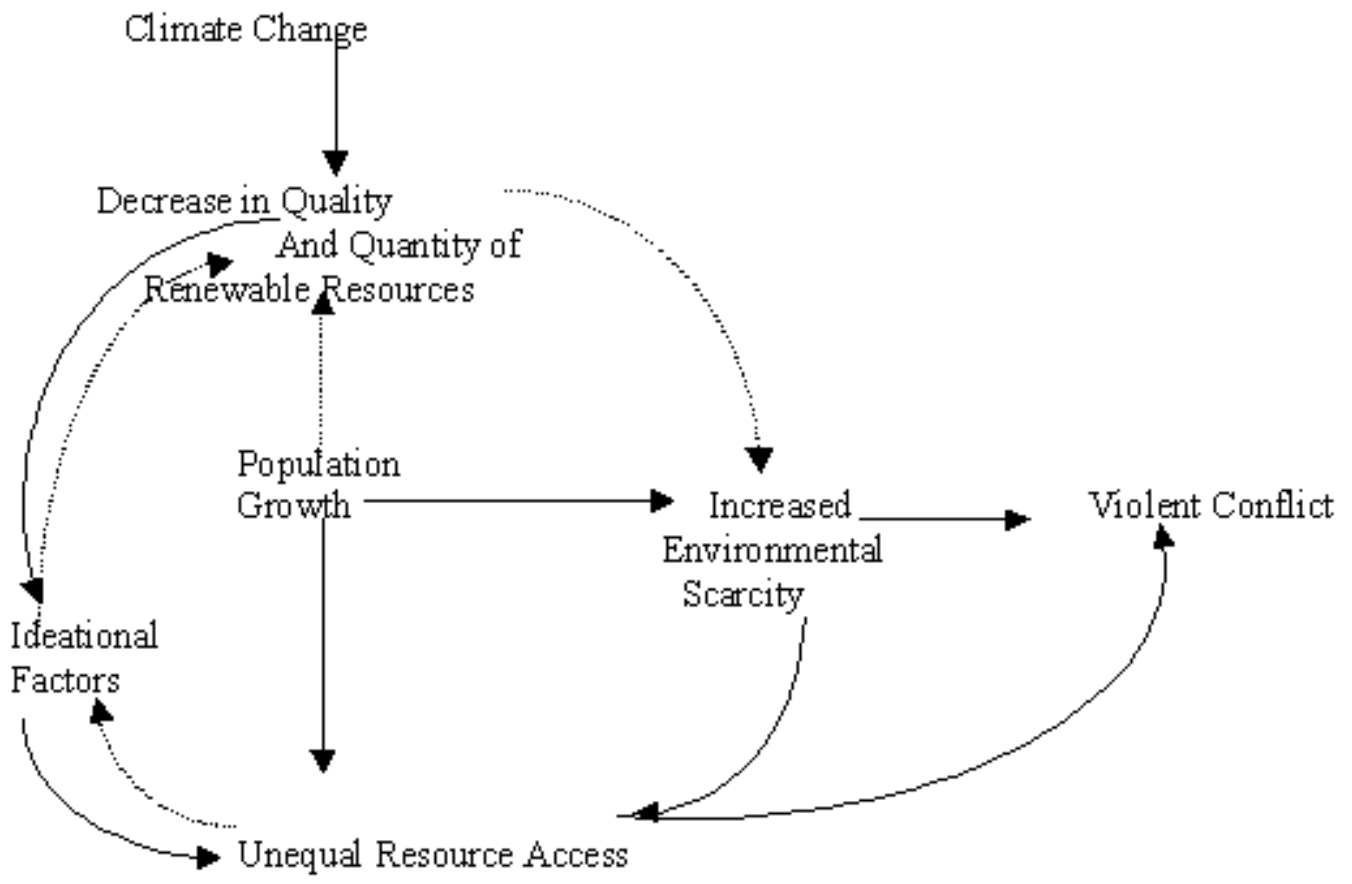

Fig. 1. Resource capture and ecological marginalization in the process of violent conflict re-modeled Note: from the original work of Homer-Dixon (1994)

Resource Capture: Resource Depletion as a result of Climate Change and Population Growth Cause Unequal Resource Access, which in turn predisposes to violent conflict

Ecological Marginalisation: Unequal Resource Access and Population Growth Cause Resource Degradation and Depletion, which leads to increased environmental Scarcity and in turn violent conflict.

Key: The broken arrow indicates ecological marginalisation

The continuous arrow indicates Resource Capture 
Table 2: Agro-ecological zones of Nigeria

\begin{tabular}{lrrrr}
\hline & \multicolumn{2}{c}{ Rainfall } & & \multicolumn{2}{c}{ Temperature } \\
\cline { 2 - 3 } \cline { 5 - 5 } Zone & $2000+$ & & 32 & 23 \\
Ultra humid & $1200-2000$ & & 33 & 21 \\
Very humid & $1100-1400$ & & 37 & 18 \\
Humid & $1000-1300$ & & 37 & 14 \\
Sub-Humid & $1400-1500$ & & 31 & 14 \\
Plateau & $1400-2000$ & & 36 & 5 \\
Montean & $600-1000$ & & 39 & 12 \\
Dry sub humid & $400-600$ & & 40 & 13 \\
Semi arid & &
\end{tabular}

Source: FGN 1997

on a mean annual rainfall of at least $120 \mathrm{~cm}$ and lowest mean monthly relative humidity at 9 a.m of not less than $70 \%$. The northern limit of Guinea Savanna zone is at approximately $100 \mathrm{~cm}$ mean annual rainfall, with the lowest mean monthly relative humidity at about $29 \%$. Guinea Savanna is found throughout the middle belt of Nigeria. The typical vegetation is open woodland with tall grasses ranges between one to three meters (m) high in open areas and trees (up to $15 \mathrm{~m}$ high) usually with short boles and broad leaves. This vegetation is subjected to fierce fires burn almost annually in the dry season; therefore, fireresistant species predominates. Many of the species in the southern areas of the Guinea Savanna zone are closely related to high forest species.

In the Sudan Savannah, a drift of sand covers most of the zone. It is seen in the northern areas of the country encompassing three geological regions, which influence the vegetation in each of these areas. For a long time, and over the years the vegetation of the Sudan Zone has been interfered with by man. Consequently, the number of thorny shrub plants (mostly Acacia) in this zone is noticeably greater than in the Guinea Zone. Grass is shorter and more feathery than in the Guinea zone. There are relatively matured woodland on high-level sites which are fairly uniform structure and appearance.

The delineation of Sahel Savanna zone is based on the $50 \mathrm{~cm}$ isohyets and less. The Zone is seen along the northeastern border of the country, and is influenced by the presence of late Chad and the Komadugu-Yobe river systems. Typically the vegetation consists of grasses, open thorn shrub savanna with scattered trees with around 4 - $9 \mathrm{~m}$ in height; most of them fine leafed and thorny, and extensive sparse grasses. Typical species are the trees Accacia raddianna,
A. Senegal, A. Laeta and Commiphora africana, the shrubs Salvadora persica, Leptadenia pyrotechnica and four species of Grewia, and the grasses Artistida stipoides, Schoenefeldia gracilis and Chloris priean.

\section{ANATOMY OF DROUGHT CONDITION IN THE GSSZ OF NIGERIA}

As observed in the previous section, climate condition in the GSSZ of Nigeria is usually at the extreme point. In some cases, annual range of rainfall goes down as low as $200 \mathrm{~mm}$, coupled with harsh temperature. The index of aridity is estimated to be within the range of 0.2-0.6metres. As shown in Table 3, a time series data of rainfall for the years 1994 - 1998, shows that some states in the zone are more affected than others, especially those that lay within the north most borders of Nigeria with Chad and Niger Republic (Sokoto, Borno, and Katsina States). The table reflects a non-directional trend in the data over the years, with previous or next years not necessarily lower or higher than the reference year. The dry land/GSSZ of Nigeria forms an undulating plain at a general elevation from about $450 \mathrm{~m}-700 \mathrm{~m}$. Unpredictability and unreliability of the climate characterizes the pattern of rainfall in this zone. As in other arid and semi-arid areas of the world, it is not just the total amount of rainfall that is important, but the distribution and timing. In this respect, the pattern of rainfall is highly varied in spatial and temporal dimensions with an inter-annual variability of between 15 and 20 percent. Average rainfall varies from the northeastern with least rainfall to the southern sub-area having the heaviest rainfall recorded.

Besides high inter-annual variability, the

Table 3: Annual mean rainfalls by State 1994-1998

\begin{tabular}{lrrlrr}
\hline & \multicolumn{5}{c}{ Annual Mean Rainfall/Year } \\
\cline { 2 - 6 } State & \multicolumn{1}{c}{1994} & \multicolumn{1}{c}{1995} & 1996 & \multicolumn{1}{c}{1997} & \multicolumn{1}{c}{1998} \\
\hline Bauchi & 1174.3 & 1023.2 & 1316 & 900.2 & 1122.6 \\
Benue & 973.2 & 1152.1 & 1158.9 & 1308.7 & 871.8 \\
Borno & 222.1 & 698.4 & 630.5 & 406.9 & 534.8 \\
Adamawa & 821.6 & 985.2 & 935.1 & 960.4 & 1043.9 \\
Kaduna & 1098.5 & 890.6 & 744 & 1240.8 & 889.9 \\
Kano & 755.5 & 515.3 & 570.5 & 1289.3 & 1397.8 \\
Katsina & 501.5 & 431.1 & 413.2 & 473.2 & \\
Niger & 806.9 & 1273.3 & 690 & 940.2 & 1237.3 \\
Sokoto & 762.1 & 337 & 714.8 & 645.5 & 845.9 \\
Kwara & 461.5 & 1409.2 & 745.5 & 1334.4 & 1349.5 \\
Plateau & 1165.9 & 833.6 & 436.2 & 1329.3 & 1261.3 \\
\hline
\end{tabular}

Source: Federal Office of Statistics, Nigeria 2001 
rainfall regimes of dry land/GSSZ of Nigeria are characterized by high concentration in few months, and intermittent violent storms. Thus, the region is by nature prone to recurrent, intense and persistent periods of drought. The intensity of drought may be short - lived or long in duration depending on the interaction among the natural push factor variable at work. Table 4 shows that in 1960-1999, there were visible occurrences of drought for a cumulative period of approximately 8-18 years in most of the desert prone frontline states of Nigeria.

Table 4: Frequency of drought occurrence in desertification Frontline states in Nigeria 1960. 1999

\begin{tabular}{lrrrrrr}
\hline States & 1960 & 1969 & $\begin{array}{r}1970 \\
-79\end{array}$ & $\begin{array}{r}1980 \\
-89\end{array}$ & $\begin{array}{r}1990 \\
-99\end{array}$ & Total \\
\hline Bauchi & - & $\mathrm{Na}$ & 4 & 6 & 2 & 12 \\
Gombe & - & $\mathrm{Na}$ & - & - & - & - \\
Borno & 1 & $\mathrm{Na}$ & 3 & 7 & 5 & 16 \\
Yobe & - & $\mathrm{Na}$ & 2 & 7 & 3 & 12 \\
Kano & 1 & $\mathrm{Na}$ & 2 & 5 & 1 & 9 \\
Jigawa & - & $\mathrm{Na}$ & - & - & - & - \\
Katsina & 1 & $\mathrm{Na}$ & 3 & 5 & 8 & 18 \\
Kebbi & - & $\mathrm{Na}$ & - & - & - & - \\
Sokoto & 1 & $\mathrm{Na}$ & 5 & 8 & 3 & 17 \\
Zamfara & - & $\mathrm{Na}$ & 3 & 3 & 3 & 9 \\
\hline
\end{tabular}

Source: Akeh et al 2004

The extent of drought condition in this zone has caused both temporary and permanent damage to the ecosystem. During such extended dry periods, the stress on the land is increased for both human and the livestock, which had left the environment into a precarious equilibrium. The trend in the drought induced by climate change is further aggravated by anthropogenic factors such as over-grazing and over-exploitation of marginal lands. Other factors include deforestation and poor irrigation practices that are influenced by changes in population and socio-economic conditions (Federal Ministry of Environment, 2004). Be that as it may, Nyong, et. al (2005)had contented and in other texts that the blame on overgrazing practices of the local population for desertification may not be absolutely true. Rather, the real problem in this zone is climate change, which has caused steadily decline in rainfall in the Sahel region of Africa since 1960s (Tanya Salseth Feau, 2005, Washington File staff Writer; Courtesy of Woodrow Wilson International Center for Scholars, Washington).

The extent and severity of drought in Nigeria has not been fully established neither the rate of progression properly documented. However, drought induced desertification is regarded as the most pressing environmental problem in some parts of Nigeria exposed to dry land, with both flora and fauna loss at fast rates. The visible sign of this phenomenon is the gradual shift in vegetation from grasses, bushes and occasional trees, to grass and bushes, and in the final stages, expansive areas of barren sand dunes. Land degradation indicators show that drought related degradations such as wind erosion, deforestation (natural loss) and forest fire have had more and far reaching negative impact on the environment compared with other agents of land degradation. However, the underlying observation is that more areas and hectares of land are affected and made unproductive as a result of drought related environmental problems. For instance the difference between the area affected in 1990-1999 and 2000-2003 indicates a steady loss from wind, deforestation and forest fire as shown in table 5. In relation to the land loss, an estimate of $50 \%$ and $75 \%$ of the desertification frontline states in Nigeria are affected by the phenomenon (Federal Ministry of Environment 2004).

Table 5: Areas affected by wind, deforestation and Savannah Forest Fire 1990-2003

\begin{tabular}{lll}
\hline Indicator & \multicolumn{2}{c}{ Area Affected } \\
\cline { 2 - 3 } & $1990-1999$ & $2000-2003$ \\
\hline Wind Erosion & $6,500,000 \mathrm{ha}$ & $9,000,000 \mathrm{ha}$ \\
Deforestation & $350,000 \mathrm{ha} / \mathrm{ann}$ & $400,000 \mathrm{ha} / \mathrm{ann}$ \\
Savannah forest fire & $100,000 \mathrm{ha} / \mathrm{ann}$ & $120,000 \mathrm{ha} / \mathrm{an}$ \\
\hline Source: FGN 2004 & &
\end{tabular}

The severity and fast rate of aridity in the Sudan and Sahel zones is not unconnected with the climate change, which has affected the pattern of rainfall in the areas since 60years. The trend and pattern of rainfall for 22 stations located within the GSSZ of Nigeria for a 6 decades period shows that there have been significant reduction in rainfall received over the years (Fasona and Omojola 2005). It is therefore clear from the figures in table 6 that for most stations located in the upper Sudan and Sahel zone of Nigeria, the deviation of rainfall from the grand mean is negative. Worst affected are Nguru, Maiduguri and Katsina areas that are located in the interior of the Sahel zone.

High water deficit associated with the GSSZ has led to more exploitation of the ground water 
Table 6: Mean decadal rainfall (1940-2000) for selected stations in GSSZ of Nigeria

\begin{tabular}{|c|c|c|c|c|c|c|c|c|c|}
\hline Station & $1940 s$ & $1950 \mathrm{~s}$ & $1960 \mathrm{~s}$ & $1970 \mathrm{~s}$ & $1980 \mathrm{~s}$ & $1990 s$ & $\begin{array}{c}\text { Total } \\
\text { decade } \\
\text { mean }\end{array}$ & $\begin{array}{c}\text { Mean } \\
\text { average } \\
\text { for all } \\
\text { decade }\end{array}$ & $\begin{array}{l}\text { Deviation } \\
\text { from the } \\
\text { mean }\end{array}$ \\
\hline Bauchi & 1121.02 & 1080.75 & 1039.29 & 1000.34 & 898.91 & 1112.54 & 6252.85 & 1042.14 & 70.8753 \\
\hline Birnin-Kebbi & & & & 715.557 & & & 715.55 & 715.557 & -255.71 \\
\hline Gusau & & 1062.04 & 945.7 & 877.21 & 646.03 & 1069.29 & 4600.26 & 920.053 & -51.213 \\
\hline Kaduna & 1076.97 & 1469.57 & 1269.62 & 1020.09 & 1116.15 & 1202.02 & 7154.42 & 1192.4 & 221.137 \\
\hline Kano & 781.39 & 909.51 & 837.44 & 706.16 & 613.98 & 1119.11 & 4967.59 & 827.932 & -143.33 \\
\hline Maiduguri & 592.5 & 723.49 & 658.07 & 582.97 & 419.17 & 601.3 & 3577.5 & 596.25 & -375.02 \\
\hline Sokoto & 657.01 & 779.54 & 693.64 & 597.8 & 538.23 & 673.6 & 3939.82 & 656.637 & -314.63 \\
\hline Yola & 924.92 & 992.43 & 844.9 & 915.8 & 832.02 & 937.75 & 5447.82 & 907.97 & -63.297 \\
\hline Nguru & 554.16 & 586.12 & 518.82 & 449.11 & 335.24 & 431.456 & 2874.91 & 479.152 & -492.11 \\
\hline Potiskum & 713.18 & 864.6 & 772.14 & 623.65 & 591.41 & 706.322 & 4271.3 & 711.884 & -259.38 \\
\hline Katsina & 682.25 & 786.31 & & 584 & 482.73 & 360.144 & 2895.43 & 579.087 & -392.18 \\
\hline
\end{tabular}

Source: Underlying Data from Fasona and Omojola, (2005)

reserve. Currently, the extraction of groundwater through boreholes and hand-dug wells is tapping one or more of the aquifers underlie the area. Continuous over-pumping of ground water will definitely lead to continuous depletion on the water table as observed by Carmalt and Tibbisalts (1969) who recorded a decline of $6.5 \mathrm{~m}$, in the mean ground water level around Maiduguri axis between 1963 and 1972. Expert options suggest that the situation is currently probably worse in most parts of the dry land areas than in the past. This however suggests for a full study of the exact recharge rate and the magnitude of the recharge in this zone.

\section{AGRICULTURE AND FOOD PRODUCTION ACTIVITIES IN THE GSSZ}

The GSSZ of Nigeria occupies more than $60 \%$ of land surface in Nigeria. The people in these areas are predominantly farmers, like in other parts of Nigeria where farming/agriculture engages over $65 \%$ of the population. However, food production activities in this zone can be discussed under types of agricultural activities, and major food produce estimates. Climate determines the location of the crops and animals and the farm routine in GSSZ of Nigeria. While grains and livestock are grown mainly in the drier north, mix crops and livestock are practiced in the middle belt zone.

Arable cropping is one of the main occupations of majority of the inhabitants in GSSZ of Nigeria, where two types of farmlands are maintained (Iloeje 1975), namely compound land and outfield. The former, generally a quarter to half an acre, is located within the compound and is intensively cultivated. It is heavily manure with household refuse and animal droppings and planted annually with garden crops like vegetable, fruits and pepper. The outfield is usually more extensive and situates some distance from the compound. It is cropped under the bush fallow system, and planted with basic food, staple, and cash crops like maize, millet sorghum, wheat, cotton and groundnuts among others. Within the outfield farms, there are also areas where tree crops like citrus are grown.

Livestock farming is also practiced widely in the GSSZ, especially in the Sudan-Savannah area where cattle, sheep, goat, poultry, horses, and donkeys are the main livestock reared. It is difficult to say how many of each of these exists because accurate records do not exist. Nevertheless, recent estimates of domestic livestock in the Nigeria indicate some increases for some species that are more drought resistant. Most of the cattle/animals that are domesticated are either kept as beast of burden or for food. A very prominent feature in the livestock farming in the GSSZ of Nigeria is the traditional pastoral nomadic livelihood with some transhumance. In this practice, mainly an occupation of the Fulani ethnic group, there are no permanent homes for the animals. The nomad pitch their tents when they need temporary rest and remove the tents when they need further movement with their cattle. Though, the herdsmen's way of life is simple and primitive, but they are intelligent enough to move their cattle as the environment demands. They move northwards in the wet season, but southward in the dry season; when the grasses in the Sudan and Sahel zones have all died away. Similarly, they drive their cattle up the plateau in the wet season 
when the valleys are tsetse fly infected, but in the dry season when the valleys are free from the pests and the plateaux are dry and patchy, they drive their cattle down. Particularly in the Sahel region, they keep their livestock near rivers where water is available for their cattle, which accounts for large concentration of cattle around Sokoto and Hadeija river valleys in the Sahel climatic zone of far non-Nigeria (Iloeje, 1975). Besides arable and livestock farming, fishing activities has been going on around major river valleys. Even though most of the rivers loose a great volume of their content during the dry seasons, some of them still retain quite considerable volume of water that is good for fishing. Major rivers in this characteristic include, Sokoto, Yobe, Gongola, Kaduna, Niger and Hedeija rivers among few others, where various types of fishes are caught in different sizes.

\section{CLIMATE VARIABILITY, FOOD PRODUCTIONAND FOOD SECURITY INTERFACE IN THE GSSZ}

Recognizing that Nigeria is confronted by the problem of drought and desertification, it is estimated that about half of Nigeria 71.2 million hectares of available agricultural land is currently being utilized. Studies have indicated that the country would suffer large ecological and economic losses if the environmental problems continue unchecked (Federal Government of Nigeria 1997). Initial estimate indicates that the cost of unsustainable development for Nigeria may be as high as US \$ 5.1 billion per year Most of the losses are likely to be in the agricultural production, which depends much on the climate condition. Any drastic change in the climate regime in Nigeria will affect the food production capacity of Nigeria because the traditional small holder farmers who use simple techniques of production and the bush fallow system of cultivation account for over ${ }^{2 / 3}$ of Nigeria's total agricultural production(Federal Government of Nigeria 1997).

The impact of climate change on the capacity of the local people to produce is further compounded by the incessant conflicts as a result of population pressure and scramble for resources (Obioha 2005, 2008). As a result of the increasing aridity and desert encroachment from the far north fringes of Nigeria around the Sahel region, there have been unplanned and chaotic population displacement and drift towards the southern axis of the GSSZ. The pressure of the migrating human and livestock population from the Sahel areas are absorbed by buffer states in the middle - belt region of the GSSZ. Already these buffer states have about $10-15 \%$ of their land area threatened by desertification due to drought phenomenon. The combined effect of migration and desertification of the buffer states leads to an intensified use of fragile and marginal ecosystem resulting into progressive degradation even in the years of normal rainfall. (Federal Ministry of Environment 2004). Additionally, pressure is put on the pasture resources by livestock from other Sahel countries, especially Chad, Niger and Cameroon. Thus, livestock from these countries are attracted to the Nigeria's GSSZ towards the northeast axis because of abundant supply fodder around the patches of the wetland area of Lake Chad and beyond, which sparks off conflicts between the Nigerians and the Cameroonians at the border fringes.

There are many conflicts, which are environmentally induced in North East Nigeria Savannah. These are conflicts over grazing land, over cattle, over water points and over cultivable land. While there are conflicts over grazing land and over cattle amongst pastoral people, there are also conflicts over cultivable land amongst peasant farmers within the same ethnic group and also between ethnic groups. Such conflicts amongst pastoralists are common and widespread in Nigeria (Obioha 2008). This is similar to what happens between the Karamajong of Uganda and the Pokot of Kenya who have been fighting over grazing land and over cattle for more than three decades (Bujra 2000). Other examples of conflicts amongst pastoralists are many in other parts of Africa: among the Somalis, Oromos, Karamojong, Pokot, and Masai among others. Similarly, conflicts for fertile and cultivable land have been taking place amongst many ethnic groups in the area like elsewhere in Africa? ${ }^{7}$.

Most of these rural based conflicts over land and cattle have been going on over a long period, with very little attention given to them. Even today most of such conflicts go unnoticed and unreported - unless large-scale killing and injuries take place and the state intervenes militarily. These conflicts go back a long way, in some cases to the pre-colonial period. However, major changes have been introduced in the countries' economies such as changes over land laws, which 
often contradict customary laws (Obioha 2000, 2002, 2004, 2008), confiscation of large tracts of land for ranching and large-scale farming, and increase in population. Most important is the rise of rural inequalities - between rich and poor/ landless farmers, between rich ranchers and poor cattle owners. These changes have led to a considerable competition for the scarce resources of land (cultivable and grazing, including water). Furthermore, environmental deterioration in land productivity and scarcity of water has contributed to the intensity of the competition. Amongst pastoral societies in particular, the system of grazing, which involves movement of large cattle herds to water points and in search of pasture, has created a serious problem. Private ownership of land has restricted these necessary movements of pastoralist and the impact has been serious and catastrophic on pastoralist societies (Bujra 2000).

As vulnerable as the GSSZ of Nigeria is, it has a high carrying capacity, being a home to over a quarter of Nigerian population. It supports about $90 \%$ of the cattle production, $2 / 3$ of the goats and sheep, and almost all the donkeys, camels and horses found in the country. Implicitly, the zone plays a dominant role in the agricultural modernization and irrigation of the country, promotion of the export crops such as cotton, groundnuts and gum Arabic and production of food crops, mostly the import substitution crops.

The interaction between climate change and agricultural production could be negative or positive. However, in the case of the GSSZ of Nigeria the interaction brings up negative results and the extent to which drought affects food production in the area and Nigeria in general can be deduced from the observation of United States Development Agency Foreign Agricultural services forecast 2006 as shown in table 7. Based on four cereal crops of GSSZ, wheat compared to other crops rice, sorghum and corn is experiencing
Table 7: Estimate of selected cereal production in Nigeria 2004-2006

\begin{tabular}{lrrr}
\hline Crop & 2004 & 2005 & 2006 \\
\hline Wheat & 60 & 60 & 60 \\
Rice & 2300 & 2700 & 2800 \\
Corn & 6500 & 7000 & 7350 \\
Sorghum & 10000 & 10500 & 10600
\end{tabular}

Source: USDA Foreign Agricultural Services 2005

static growth between 2005/06 and 2006/07 because it is the most climate dependent crop. Wheat production is not expected to expand significantly beyond this level due to local climate conditions, which are not suitable for wheat production in the GSSZ of Nigeria.

Generally, agricultural production has not performed very well in Nigeria owing to some other factors that may not be very necessary to capture in this paper. Table 8 shows how agriculture is disfavoured, which also points out to the fact that this may not be unconnected with the climate variability and changes that affect the potentials of agriculture.

From average annual growth rate perspective, most population and agricultural labour force indicators and agricultural food production have been on steady decline between 1980 and 2003 as shown in Table 9.

Table 9: Labour forces and agricultural food production

\begin{tabular}{lcc}
\hline Indicators & $1980-1990$ & $1990-2003$ \\
\hline Rural population & 1.7 & 1.0 \\
Agric labour force & 0.2 & 0.3 \\
Agric production & 5.6 & 5.6 \\
Per capita agric prod & 2.6 & 0.7 \\
Food production & 5.5 & 3.6 \\
Per person food production & 2.5 & 0.7 \\
Food production & 5.5 & 3.6 \\
Per person food. Prod. & 2.5 & 0.7 \\
\hline
\end{tabular}

Source: Underlying Data from FAOSTAT, 2005;

World Bank-World Development Indicators, 2005

Table 8: Agricultural production labour and land capital indicators (1992-2000)

\begin{tabular}{|c|c|c|c|c|c|c|c|}
\hline Indicators & Unit & 1979-81 & 1991 & 2000 & 2001 & 2002 & 2003 \\
\hline \multicolumn{8}{|l|}{ Population and Agric. Labour } \\
\hline Rural Population & Percent & 73 & 65 & 56 & 55 & 54 & 53 \\
\hline $\begin{array}{l}\text { Agric labour force/T. Lab. } \\
\text { Land use }\end{array}$ & Percent & 54 & 43 & 33 & 32 & 32 & 31 \\
\hline Arable land + perm. Crops & $1000 \mathrm{HA}$ & 30360 & 32099 & 30850 & 31200 & 33000 & - \\
\hline Arable land & $1000 \mathrm{HA}$ & 27827 & 29564 & 28200 & 28500 & 20200 & - \\
\hline Irrigated land & $1000 \mathrm{HA}$ & 200 & 220 & 233 & 233 & 233 & \\
\hline
\end{tabular}

Source: Underlying Data from FAOSTAT, 2005; World Bank-World Development Indicators, 2005 
Climate Variability Proxy (Rainfall) and Food Production Nexus in GSSZ

Food items production in the GSSZ of Nigeria may be dependent on the climate variability regime, especially on the amount of rainfall. From 1960-2004, there has been more drought than rainfall in the GSSZ of Nigeria. To be specific, in Katsina for example, the number of years with drought is 29 while those with rain are just 16 . This means that Katsina is still very prone to drought. The drought implication from this is that Katsina has experienced more drought years compared to the normal years of rainfall, which could cause serious shortage of water supply in the city and state as the rivers dry. This situation in turn decreases the quantity of water available for use. At this instance, agricultural project may be seriously hampered, as it is not likely to be successful because of the low availability of water. Industries that make use of a lot of water mill by now have to find alternative means of water supply as the state may not be able to provide them with water and they cannot depend on rain. Their best bet is to opt for borehole drilling. Due to lack of specific data to demonstrate the relationship between drought condition and agricultural production, the supposition of fish production as a proxy will suffice for this discourse. Below is the result of an analysis of the interface between rainfall and fish production (Drought Situation over Katsina State 1960-2004)

\section{Food Production and Food Security Scenario GSSZ of Nigeria}

The food production outputs and the level of agricultural production intensification are shown in Tables 10-18. The interface between adverse climate condition characterized by extreme dryness or drought is not an issue to be questioned with regard to it being real in Africa in general and Nigeria in particular. For instance during the 1972-1973 drought, in the Savannah zone of Nigeria, about 300,000 animals died and farm yields dropped by up to $60 \%$ in Nigeria. This implies that drought may portend adverse effect on food production, resuting to food insecurity. However, the extent to which food production and security arise from drought phenomenon in Nigeria is not very certain. What is known according to Michael (2006) is that drought has

Table 10: Estimate of fish production in GSSZ by State 1991-2000

\begin{tabular}{|c|c|c|c|c|c|c|c|c|c|c|}
\hline \multirow[b]{2}{*}{ State } & \multicolumn{10}{|c|}{ Fish Production Per Year } \\
\hline & 1991 & 1992 & 1993 & 1994 & 1995 & 1996 & 1997 & 1998 & 1999 & 2000 \\
\hline Bauchi/Gombe & 488 & 405 & 173 & 172 & 144 & 154 & 159 & 53 & 67 & 66 \\
\hline Borno/Yobe & 71832 & 46398 & 47266 & 34657 & 74852 & 96413 & 97712 & 94344 & 82399 & 79307 \\
\hline Taraba/Adamawa & 14331 & 13558 & 13568 & 13089 & 11897 & 11494 & 11105 & 16023 & 18344 & 22003 \\
\hline Kaduna & 6341 & 1530 & 756 & 1101 & 1096 & 1373 & 1276 & 6700 & 6314 & 5153 \\
\hline Kano/Jigawa & 1056 & 838 & 735 & 996 & 1050 & 565 & 837 & 822 & 1022 & 843 \\
\hline Katsina & 801 & 1109 & 547 & 520 & 706 & 591 & 695 & 768 & 685 & 727 \\
\hline Niger & 1671 & 1076 & 1019 & 1024 & 1554 & 1193 & 995 & 1391 & 876 & 1219 \\
\hline $\begin{array}{l}\text { Sokoto/Kebbi/ } \\
\text { Zamfara }\end{array}$ & 16442 & 25428 & 26161 & 54144 & 31844 & 53815 & 68015 & 55745 & 89511 & 81007 \\
\hline
\end{tabular}

Source: Federal Office of Statistics, Nigeria

Table 11: Estimated percentage growth of fish production per annum per State 1992-2000

\begin{tabular}{lrrrrrrrrrrr}
\hline State & $\begin{array}{r}\text { Annual } \\
\text { Ave }\end{array}$ & 1992 & 1993 & 1994 & 1995 & 1996 & 1997 & 1998 & 1999 & 2000 & Ave \\
\hline Bauchi/Gombe & 188.1 & -17.01 & -57.28 & -0.58 & -16.28 & 6.94 & 3.25 & -66.67 & 26.42 & -1.49 & -13.63 \\
Borno/Yobe & 72518 & -35.41 & 1.87 & -26.68 & 115.98 & 28.80 & 1.35 & -3.45 & -12.66 & -3.75 & 7.34 \\
Taraba/ & 14541.2 & -5.39 & 0.07 & -3.53 & -9.11 & -3.39 & -3.38 & 44.29 & 14.49 & 19.95 & 6.00 \\
$\quad$ Adamawa & & & & & & & & & & & \\
kaduna & 3164 & -75.87 & -50.59 & 45.63 & -0.45 & 25.27 & -7.06 & 425.08 & -5.76 & -18.39 & 37.54 \\
Kono/Jigawa & 876.4 & -20.64 & -12.29 & 35.51 & 5.42 & -46.19 & 48.14 & -1.79 & 24.33 & -17.51 & 1.66 \\
Katsina & 714.9 & 38.45 & -50.68 & -4.94 & 35.77 & -16.29 & 17.60 & 10.50 & -10.81 & 6.13 & 2.86 \\
Niger & 1201.8 & -35.61 & -5.30 & 0.49 & 51.76 & -23.23 & -16.60 & 39.80 & -37.02 & 39.16 & 1.49 \\
Sokoto/Kebbi/ & 50211.2 & 54.65 & 2.88 & 106.96 & -41.19 & 69.00 & 26.39 & -18.04 & 60.57 & -9.50 & 27.97 \\
$\quad$ Zamfara & 143415.6 & -20.02 & -0.13 & 17.15 & 16.50 & 34.48 & 9.18 & -2.74 & 13.29 & -4.46 & 7.03 \\
\hline
\end{tabular}

Source: Data Analysis 
caused serious food insecurity situation in some African countries, including Nigeria. Also in Eritrea, because of lack of seasonal rains and aftermath of war with Ethiopia, one million of the country's 3.7 million people face drought and starvation. Farmers in Gambia are despairing as shortage of rain is causing new seedlings to wilt and die off. The international Institute of Tropical Agriculture (IITA) in Nigeria has also estimated that by 2010 around 300 million people in subSaharan Africa, nearly a third of the population, will be malnourished (Michael, 2006). Most indicators examined pointed out to the fact that food production in Nigeria, especially in the GSSZ of Nigeria has not witnessed a steadily appreciable growth in the last two decades.

For the purpose of ascertaining whether climate change in the GSSZ of Nigeria has any implication on food production in the country in the recent time, some cereals that are dominant produce of the area and fish are used as reference points of analysis. For fish production, Table 10 shows quantity of fish production in the selected states in the zone per annum, while in Table 11, the annual percentage growth indicates a drop in 1992, 1995, 1998, and 2000, relative to previous year, with the worst situation being in 1995 at a negative growth of $-41 \%$. Among all the states in the analysis, Bauchi /Gombe experienced the least fish production growth in the negative direction, which are among the north most states in the country nearer to the Sahara Desert.

Table 12 shows estimate of areas harvested with major crops from 1991-2000. An insight into climate situation, using growth change analysis in the areas harvested with major crops as illustrated in Table 13 indicates from a frther percentage growth analysis that the estimated areas harvested had a drop in 1992 and 1999 relative to the previous years for most of the crops. Millet, Guinea Corn and Cotton had more years of decrease in the expanse of areas harvested, because of there are relatively more sahel environment where these crops are grown than there are in bean production areas.

The result in Table 14 and further analysis as done in table 15 show that yield per hectare decreased in 1993, 1996, 1997 and 1999. Similarly, total output for major crops experienced decline in 1992 and 1999 relative to the previous years as indicated in Tables 16 and 17.

The general situation of food production and security in Nigeria depicts a state of food insecurity as demonstrated in the previous tables. Food and population growth comparison estimate reveled that the annual population growth rate in the country has by far exceeded the growth rate in food production (Fig. 2), as the food deprivation prevalence is on the increase, from 8.9 million in 1997 to 11.5 million in 2003 (Fig 3). As a result of this, child nutritional status index shows $9.3 \%$ as indicated in children's wasting and stunted growth rate typical in Nigeria.(FOA, 2006)

Similar to the above statistics, further statistical analysis further shows that there has been an established gap between food production and food demand for the cereal crops in Nigeria from 1995-1997 as shown in Table 18.

Table 12: Estimated area harvested with major crops in GSSZ 1991-2000 in 000Hecters

\begin{tabular}{lrrrrrrrrrr}
\hline Crops & 1991 & 1992 & 1993 & 1994 & 1995 & 1996 & 1997 & 1998 & 1999 & 2000 \\
\hline Millet & 2594 & 1941 & 5113 & 5138 & 4268 & 4409 & 4400 & 4376 & 4395 & 4390 \\
Guinea Corn & 3052 & 2973 & 6236 & 6392 & 5895 & 5896 & 5803 & 5910 & 5870 & 5861 \\
Groundnut & 846 & 755 & 1949 & 1979 & 2539 & 2611 & 2486 & 2542 & 2546 & 2525 \\
Beans & 1858 & 1876 & 3501 & 3589 & 4814 & 4888 & 5583 & 6099 & 5522 & 5735 \\
Cotton & 117 & 73 & 485 & 521 & 224 & 228 & 200 & 189 & 206 & 198 \\
\hline
\end{tabular}

Source: Federal Office of Statistics, Nigeria

Table 13: Estimated \% growth of areas harvested with major crops per annum, 1992-2000

\begin{tabular}{lrrrrrrrrrrr}
\hline Crops & $\begin{array}{r}\text { Annual } \\
\text { Ave }\end{array}$ & 1992 & 1993 & 1994 & 1995 & 1996 & 1997 & 1998 & 1999 & 2000 & Ave \\
& 4102.4 & -25.17 & 163.42 & 0.49 & -16.93 & 3.30 & -0.20 & -0.55 & 0.43 & -0.11 & 13.85 \\
Millet & 5388.8 & -2.59 & 109.75 & 2.50 & -7.78 & 0.02 & -1.58 & 1.84 & -0.68 & -0.15 & 11.26 \\
Guinea Corn & 2077.8 & -10.76 & 158.15 & 1.54 & 28.30 & 2.84 & -4.79 & 2.25 & 0.16 & -0.82 & 19.65 \\
Groundnut & 4346.5 & 0.97 & 86.62 & 2.51 & 34.13 & 1.54 & 14.22 & 9.24 & -9.46 & 3.86 & 15.96 \\
Beans & 244.1 & -37.61 & 564.38 & 7.42 & -57.01 & 1.79 & -12.28 & -5.50 & 8.99 & -3.88 & 51.81 \\
Cotton & 16159.6 & -10.03 & 126.88 & 1.94 & 0.69 & 1.65 & 2.44 & 3.49 & -3.02 & 0.92 & 13.88 \\
& & & & & & & & & & & \\
\hline
\end{tabular}

Source: Data Analysis 
Table 14: Estimated yield per hectare of major crops in GSSZ 1991-2000 in 000 tonnes, 1992-2000

\begin{tabular}{lrrrrrrrrrr}
\hline Crops & 1991 & 1992 & 1993 & 1994 & 1995 & 1996 & 1997 & 1998 & 1999 & 2000 \\
\hline Millet & 1003 & 1253 & 549 & 574 & 882 & 889 & 915 & 1444 & 1329 & 1372 \\
Guinea Corn & 1024 & 1048 & 574 & 602 & 1106 & 1155 & 1080 & 1426 & 1204 & 1175 \\
Groundnut & 937 & 918 & 398 & 451 & 917 & 1014 & 962 & 997 & 992 & 984 \\
Beans & 420 & 516 & 317 & 419 & 458 & 480 & 460 & 471 & 453 & 457 \\
Cotton & 1376 & 1932 & 346 & 353 & 1304 & 882 & 990 & 1841 & 1694 & 1843 \\
\hline
\end{tabular}

Source: Federal Office of Statistics, Nigeria

Table 15: Estimated \% growth of yield per hectare for major crops per annum, 1992-2000

\begin{tabular}{|c|c|c|c|c|c|c|c|c|c|c|c|}
\hline Crops & $\begin{array}{r}\text { Annual } \\
\text { Ave }\end{array}$ & 1992 & 1993 & 1994 & 1995 & 1996 & 1997 & 1998 & 1999 & 2000 & Ave \\
\hline Millet & 1021.0 & 24.93 & -56.19 & 4.55 & 53.66 & 0.79 & 2.92 & 57.81 & -7.96 & 3.24 & 9.31 \\
\hline Guinea Corn & 1039.4 & 2.34 & -45.23 & 4.88 & 83.72 & 4.43 & -6.49 & 32.04 & -15.57 & -2.41 & 6.41 \\
\hline Groundnut & 857.0 & -2.03 & -56.64 & 13.32 & 103.33 & 10.58 & -5.13 & 3.64 & -0.50 & -0.81 & 7.31 \\
\hline Beans & 445.1 & 22.86 & -38.57 & 32.18 & 9.31 & 4.80 & -4.17 & 2.39 & -3.82 & 0.88 & 2.87 \\
\hline \multirow[t]{2}{*}{ Cotton } & 1256.1 & 40.41 & -82.09 & 2.02 & 269.41 & -32.36 & 12.24 & 85.96 & -7.98 & 8.80 & 32.93 \\
\hline & 4618.6 & 19.05 & -61.46 & 9.84 & 94.54 & -5.29 & -0.29 & 40.21 & -8.21 & 2.80 & 10.13 \\
\hline
\end{tabular}

Source: Data Analysis

Table 16: Estimated output of major crops production in GSSZ 1991-2000 in 000met tonnes

\begin{tabular}{lrrrrrrrrrr}
\hline Crops & 1991 & 1992 & 1993 & 1994 & 1995 & 1996 & 1997 & 1998 & 1999 & 2000 \\
\hline Millet & 2602 & 2432 & 2809 & 2949 & 3760 & 5921 & 5917 & 6317 & 5842 & 6025 \\
Guinea Corn & 3124 & 3116 & 3577 & 3845 & 6517 & 7608 & 7959 & 8430 & 7066 & 6885 \\
Groundnut & 793 & 693 & 776 & 893 & 2329 & 2647 & 2392 & 2535 & 2525 & 2484 \\
Beans & 780 & 968 & 1109 & 1503 & 2203 & 2143 & 2488 & 2875 & 2502 & 2622 \\
Cotton & 161 & 141 & 168 & 184 & 292 & 301 & 308 & 348 & 349 & 365 \\
\hline
\end{tabular}

Source: Federal Office of Statistics, Nigeria

Table 17: Estimated annual percentage growth of total output of major crops, 1992-2000

\begin{tabular}{lrrrrrrrrrrr}
\hline Crops & $\begin{array}{r}\text { Annual } \\
\text { Ave }\end{array}$ & 1992 & 1993 & 1994 & 1995 & 1996 & 1997 & 1998 & 1999 & 2000 & Ave \\
& 4457.4 & -6.53 & 15.50 & 4.98 & 27.50 & 57.47 & -0.07 & 6.76 & -7.52 & 3.13 & 11.25 \\
Millet & 5812.7 & -0.26 & 14.79 & 7.49 & 69.49 & 16.74 & 4.61 & 5.92 & -16.18 & -2.56 & 11.12 \\
Guinea Corn & 1806.7 & -12.61 & 11.98 & 15.08 & 160.81 & 13.65 & -9.63 & 5.98 & -0.39 & -1.62 & 20.36 \\
Groundnut & 1919.3 & 24.10 & 14.57 & 35.53 & 46.57 & -2.72 & 16.10 & 15.55 & -12.97 & 4.80 & 15.72 \\
Beans & 261.7 & -12.42 & 19.15 & 9.52 & 58.70 & 3.08 & 2.33 & 12.99 & 0.29 & 4.58 & 10.91 \\
Cotton & 14257.8 & -1.47 & 14.82 & 11.08 & 61.09 & 23.30 & 2.38 & 7.56 & -10.83 & 0.53 & 12.05 \\
& & & & & & & & & & & \\
\hline
\end{tabular}

Source: Data Analysis

Table 18: Food demand and production differences 1995-1997

\begin{tabular}{|c|c|c|c|c|c|c|c|c|c|}
\hline \multirow[t]{2}{*}{ Commodity } & \multicolumn{3}{|c|}{ Projected Demand 5\% growth } & \multicolumn{3}{|c|}{ Estimated output } & \multicolumn{3}{|c|}{ Gaps } \\
\hline & 1995 & 1996 & 1997 & 1995 & 1996 & 1997 & 1995 & 1996 & 1997 \\
\hline Rice & 2918 & 3064 & 3217 & 3203 & 3122 & 3230 & 285 & 58 & 13 \\
\hline Maize & 4288 & 4502 & 4727 & 6931 & 6217 & 6285 & 2643 & 1709 & 1558 \\
\hline Sorghum & 7327 & 7693 & 8078 & 6997 & 7514 & 7954 & -330 & -179 & -124 \\
\hline Millet & 6514 & 6474 & 6798 & 5563 & 5803 & 5997 & -951 & -671 & -801 \\
\hline Wheat & 2982 & 3131 & 3288 & 44 & 47 & 49 & -2938 & -3084 & -3239 \\
\hline Groundnut & 911 & 956 & 1004 & 1579 & 2078 & 2101 & 668 & 1122 & 1097 \\
\hline
\end{tabular}

Source: Nigeria; Directory of Soil Institutions and Experts in Africa, 2002

Note: The projection for Demand here was based on $5 \%$ growth irrespective of the actual or estimated population growth in the country. 


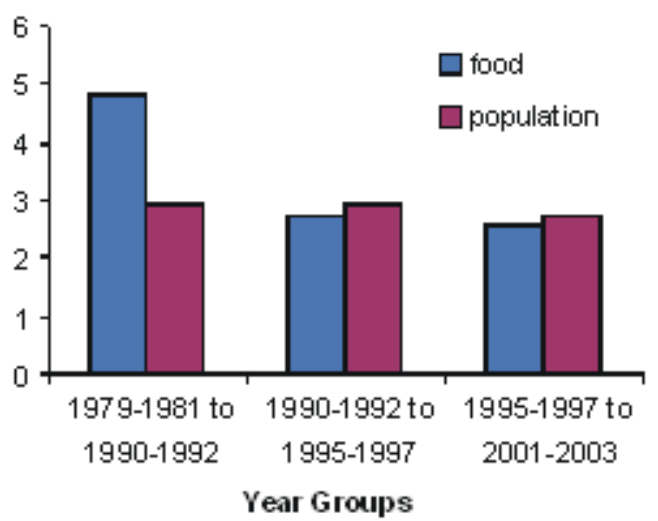

Fig. 2. Difference in food and population growth 1979-2003

Source: Food and Agricultural Organization (2006)

FAOSTAT: Food Security Statistics- Nigeria

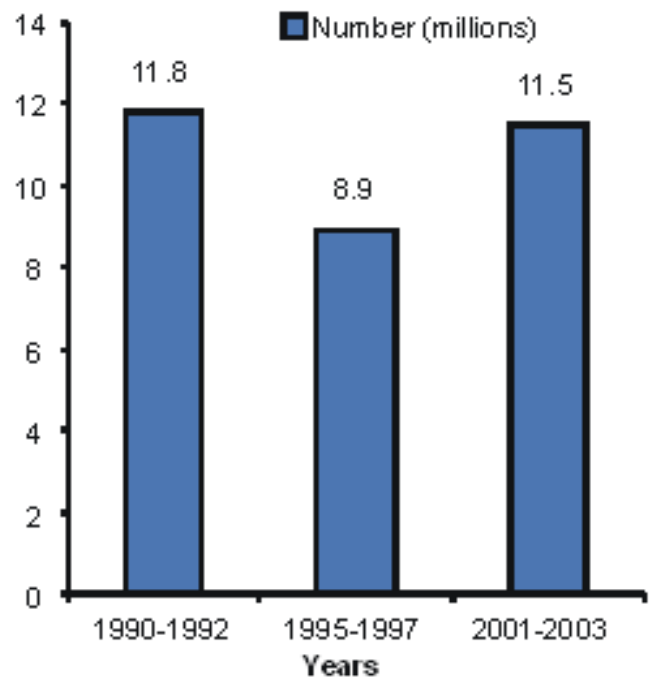

Fig. 3. Food deprivation estimate

Source: Food and Agricultural Organization (2006) FAOSTAT: Food Security Statistics- Nigeria

\section{CONCLUDINGREMARKS}

Drought and desertification are the most important twin environmental problems affecting the 15 northernmost states of Nigeria.. This climate problem has resulted to decline in arable and fish production in most states of the zone, especially the north most ones that experience more dryness and desert encoeachment. The government, and at some instances in collaboration with donor countries, international organiza- tions and institutions, have done a lot to combat desertification, and mitigate the effects of drought since the beginning of the 1970s. Efforts have been made through more efficient utilization and alternative sources of fuel wood, promulgation of State Edicts, afforestation and reforestation programmes. Despite all these efforts, desertification has continued its down-south movement, which currently renders the areas north of latitude 15 are prone to desertification. These processes coupled with the effects of drought have continued to cripple the socio-economic lives of the people living in the affected areas. The negative impacts of this climate change on the people call for urgent actions to check the desert encroachment currently estimated at about $1 \mathrm{~km}$ annually, and institutionalize drought-ameliorating measures, which should be periodically reviewed.

\section{NOTES}

1 Four types of drought can be identified:

1) Permanent Drought: This occurs in arid areas where at all seasons, precipitation is not enough to satisfy the water needs of plants. 2) Seasonal Drought: Occurs in areas with well defined wet and dry seasons especially in the tropics owing to seasonal changes in the atmospheric circulation patterns.3) Contingent Drought: This occurs as a result of irregular and variable rainfall. This is characteristic of sub humid and humid areas and it occurs when the rain fails to fall over a period of time. 4) Invisible Drought: occurs any time the daily supply of moisture from the soil or falling precipitation fails to equal the daily water needs of plants.

2 Meteorological Drought is defined usually on the basis of the degree of dryness (in comparison to some "normal" or average amount) and the duration of the dry period. Definitions of meteorological drought must be considered as region specific since the atmospheric conditions that result in deficiencies of precipitation are highly variable from region to region. Agricultural drought links various characteristics of meteorological (or Hydro logical) drought to agricultural impacts, focusing on precipitation shortages, differences between actual and potential evopotranspiration, soil water deficits, reduced ground water of reservoir levels and so forth. Hydrological drought is associated with the effects of period of precipitation (including snowfall) shortfalls on surface or subsurface water supply (i.e. stream flow, reservoir and lake levels, ground water).

3 "Food insecurity is the inability of a household or nation to meet target consumption levels in the face of fluctuating production, prices and incomes". Food insecurity may be chronic or transitory. In chronic food insecurity, there is continuous inadequate diet and nutrition caused by the household's inability to acquire food. It therefore afflicts households that persistently 
lack the ability to either buy food or produce their own. On the other hand, transitory food insecurity results from a temporary decline in household access to food due mainly to instability in food prices, production, household income or a combination of these factors (Reutlinger et al. (1986)

4 GSSZ will be used interchangeably with Savannah in the whole of this discourse

5 Activity per capita, in turn, is a function of available physical resource, which includes non-renewable resources such as animals, and renewable resources such as water, forests, and agricultural land and ideational factors, including institutions, social relations, preferences and beliefs.

6 Ideational factors are broad and complex social and psychological context. It includes patterns of land distribution; family and community structure; the economic and legal incentives to consume and produce goods, including the system of property rights; perceptions of the probability of long-rum societal stability; historically noted patterns of trade and interaction with societies; the distribution of coercive power within and among nations; the form and effectiveness of institutions of governance; and metaphysical beliefs about the relationship between humans and nature.

7 Examples of large-scale conflicts over cultivable land (involving ethnic groups) are not, suspect, as frequent as those among the pastoralists. Nevertheless, there are recent examples of well-reported conflicts in Kenya (Rift Valley), Nigeria (Ife and Modakeke Yoruba communities), the DRC (between the Hema and Lendu, in Ituri District) and in Ghana

\section{REFERENCES}

Bujra A 2000. African Conflicts: Their Causes and Their Political and Social Environment. Paper presented at the Ad Hoc Experts Group Meeting on the Economics of Civil Conflicts in Africa, in UNECA, Addis Ababa, April 7 to 82000

Ehrlich P, Ehrlich A 1990. The Population Explosion, London: Hutchinson.

Fasona MJ, Omojola AS 2005. Climate Change, Human Security and Communal Clashes in Nigeria. Paper prepared for Human Security and Climate Change Conference in Asker, Oslo, June 21 to 232005

Federal Government of Nigeria 1997. Report of expert panel on Nigeria: Country Profile Implementation Action of Agenda 21: Review of Progress made since the United Nations Conference on Environment, 1992. Information Provided by the Government of Nigeria to United Nations Commission on Sustainable Development Fifth Session, in New York April 7 to 25 1997. www.un.org/dpcsd/earthsummit

Federal Ministry of Environment 2004. Expert Report on Combating Desertification and Mitigating the effects of drought in Nigeria; A revised National Report on the implementation of United Nations Convention to Combat Desertification in those countries experiencing drought and Desertification Particularly in Africa. Abuja: Federal Ministry of Environment

Federal Government of Nigeria 1997. Drought management in Nigeria: What can people do to minimize its impact? Abuja: Federal Ministry of Environment

Federal Government of Nigeria 1998. Sustainable watershed management: An awareness. Abuja: Federal, Ministry of Water Resources \& Rural Development.

Fiki C, Lee B 2004. Conflict Generation, Conflict management and Self-organizing capabilities in Drought prone Rural Communities in North East Nigeria: A Case Study. Journal of Social Development in Africa, 19(2): 25-48

Food and Agricultural Organisation 2006. Food Security Statistics-Nigeria; FAOSTAT. Rome: Food and Agricultural Organisation .

Food and Agricultural Organization 2005. Food and Agricultural Indicators, FOASTAT. Rome, Food and Agricultural Organisation

Homer-Dixon TF 1994. Environment scarcity and Violent Conflict: Evidence from cases. International Security. 19(1): 5-40. Peace and Conflict Studies Programme, University of Toronto,

Homer-Dixon TF 1991. On the threshold: Environmental changes as causes of Acute Conflict International Security. 16(2) :76-116. Trudea Centre for Peace and Conflict Studies, University of Toronto.

Iloeje NP 1975 A New Geography of Nigeria. Ibadan: Longman Limited.

Michael Meron Tesfa 2006. Drought Spreads across Continent. Africa, May 2006

Nyong A, Fiki C 2005. Drought-Related Conflicts, Management and Resolution in the West African Sahel. A paper presented at Human Security and Climate Change Conference in Asker, Oslo, June 21 to 23,2005

Obioha E 2004. Changing Land Reforms and Violent Conflict over Land in Africa: Implications for Effective Preventing, Managing and Resolving Strategies. Paper presented at the $14^{\text {th }}$ annual conference of Pan African Anthropological Association, at University of Ghana, Legon, August 2 to 6, 2004

Obioha E 2005. Climate Change, Population Drift and Violent Conflict over Land Resources in North Eastern Nigeria. A paper presented at Human Security and Climate Change Conference at Asker, Oslo, June 21 to 23,2005

Obioha EEN 2000. Ethnic Conflicts and the Problem of Resolution in Contemporary Africa: A Case for African Options and Alternatives., in, P. Nkwi (ed), The Anthropology of Africa: Challenges for the $21^{\text {st }}$ Century. ICASSRT Monograph 2. pp 300-307.

Obioha EE 2002. From Leasers to Lease Holders: the Dilemma of Rural African Peasants in Changing Land Reforms in Contemporary African Nation States. Paper prepared for the $10^{\text {th }}$ Annual General Meeting Assembly of CODESRIA, in Kampala, Uganda, December 8 to 12,2002

Obioha EE 2008. Climate Chamge, Population Drift and Violent Conflict over Land Resources in Northeastern Nigeria. Journal of Human Ecology, 23(4): 311-324

Okorie FC 2003. Studies on Drought In the Sub-Saharan Region of Nigeria Using Satellite Remote Sensing and Precipitation Data. Unpublished Working paper. University of Lagos 
Olayemi JK 1996. Report of a Research Study on Food Security in Nigeria. Ibadan: Development Policy Center

Reutlinger S, Pellekan JVH 1986. Poverty and Hunger: Issues and Options for Food Security in Developing Countries. Washington, D.C: World Bank.

Reuveny F 2005. Environmental Change, Migration and Conflict: Theoretical Analysis and Empirical
Exploration. A paper presented at Human Security and Climate Change Conference in Asker, Oslo June 21-23, 2005

USDA Foreign Agricultural Service 2006. Nigeria Grain and Feed Annual 2006 Gain Report- N16007. New York: Global Agriculture Information Network

World Bank 2005. World Development Indicators. Washington DC: World Bank 